\title{
Distribuição Regional das Receitas e Despesas do Governo Central no II Reinado, 1844-1889
}

\author{
- ANDRÉ VILLELA*
}

\begin{abstract}
RESUMO
Uma das características mais marcantes da história política brasileira na segunda metade do século XIX foi a centralização de poderes, decisões e recursos econômicos no Rio de Janeiro, sede do governo imperial. Esta primazia do governo imperial sobre os governos provinciais e municipais se manifestava tanto em termos de atribuições quanto dos recursos fiscais de que dispunha. $O$ objetivo do artigo é medir a contribuição relativa das províncias dos chamados Norte e Sul do Império para o total das receitas e despesas do governo central. Os resultados a que se chegou indicam uma contribuição desproporcional das províncias do Norte para a arrecadação central, o que vai ao encontro das observações de contemporâneos, bem como pesquisas anteriores sobre o tema.
\end{abstract}

\section{Palavras-CHave}

Brasil, II Reinado, fiscalidade, centralização

\section{ABSTRACT}

One of the most striking features of Brazilian political history in the second half of the nineteenth century was the extent of centralization of power, decisions and economic resources in Rio de Janeiro, seat of the central government. This primacy of the imperial over the provincial and local governments was revealed in both its attributions and the fiscal resources it commanded. The article aims to measure the relative contributions of the provinces of the so-called North and South of the Empire to the total amount of receipts and expenditures of the central government. The results indicate a disproportionate contribution of the Northern provinces to overall collection, thus confirming contemporaries' views and earlier research on this issue.

\section{KEY WORDS}

Brazil, Second Reign, fiscal matters, centralization

\section{JEL CLASSIFICATION}

NI6, N46

+ O autor agradece os comentários detalhados de dois pareceristas anônimos indicados pela Estudos Econômicos e a Natália Levy pela assistência de pesquisa. Uma versão preliminar do artigo foi apresentada no XXXII Encontro Nacional da Anpec, realizado em dezembro de 2004 em João Pessoa, onde recebeu os generosos comentários do Prof. Pedro César Dutra Fonseca. O trabalho contou com o apoio do CNPq, por meio de uma Bolsa de Produtividade de Pesquisa.

* Professor do Mestrado em Economia Empresarial (UCAM) e da EPGE/FGV. E-mail: andre.villela@fgv.br. End. para contato: Praia de Botafogo, $190-3^{\circ}$ and. - CEP 22253-900. Rio de Janeiro - RJ.

(Recebido em março de 2005. Aceito para publicação em agosto de 2006). 


\section{INTRODUÇÃO}

A historiografia política sobre o período imperial consagrou o tema da centralização monárquica como de capital importância para se compreender, entre outros, aspectos ligados à consolidação de uma elite agrária e escravista no poder, a manutenção da integridade territorial e as relações entre o poder central e as províncias. Em muitos casos, esta literatura valeu-se de cuidadosa análise da distribuição funcional dos gastos públicos em anos selecionados para daí inferir aspectos do relacionamento do poder central com os centros regionais de poder. Exemplo disto são os trabalhos de Carvalho (1996), Colson (1979), Mello (1999) e Graham (1977).

Uma característica comum a estas contribuições é a de se restringirem a alguns anos específicos, entre outras razóes, pelo trabalho computacional que a compilação e tratamento de uma longa série de dados anuais exige. ${ }^{1}$ Porém, após um levantamento exaustivo da coleção dos Balanços da Receita e Despeza do Imperio para o período 1844-5 a 1889, tornou-se possível estender a análise desenvolvida por esses autores, direcionando-a para uma faceta ainda pouco explorada na historiografia e que diz respeito à distribuição regional das receitas e despesas do governo imperial. Com isso, procura-se estudar a dimensão fiscal da centralização política, dando continuidade a exercício desenvolvido originalmente por Tavares Bastos (1937) para apenas um ano (1866-7), como também contribuir, indiretamente, para a extensa literatura tratando dos aspectos políticos da centralização monárquica.

Neste sentido, o objetivo do artigo é comparar a contribuição de cada região para a receita do governo central com a repartição regional dos gastos do governo durante o II Reinado. Para tanto, nas seções que se seguem é desenvolvida análise da distribuição, entre os chamados Norte e o Sul do Império, ${ }^{2}$ das receitas e despesas do governo central. ${ }^{3}$ Antes, porém, discute-se muito brevemente a relação entre o fenômeno da centralização monárquica e sua base material (fiscal). Ao final do artigo são resumidas as principais conclusões e propostos caminhos para possíveis desdobramentos da pesquisa.

1 A exceção é Graham (1977), que cobre um período de mais de duas décadas.

2 No século XIX, o Norte do Império correspondia às regiôes Norte e Nordeste atuais, ao passo que o Sul englobava as provinciais do Sul, Sudeste e do Centro-Oeste.

3 Ressalta-se desde já que o enfoque aqui adotado não pressupõe homogeneidade de interesses das diversas províncias dentro de cada região. Tal suposição não apenas seria factualmente incorreta, como iria de encontro a uma vasta literatura que ressalta conflitos intra-regionais, como no caso das disputas entre províncias mediterrâneas e litorâneas no Norte ou, de forma mais dramática ainda, entre São Pedro do Rio Grande do Sul e a Corte (Rio de Janeiro) ao longo das décadas. Sou grato ao Prof. Pedro César Dutra Fonseca por insistir na importância desta ressalva ao enfoque aqui adotado. 


\section{CENTRALIZAÇÃO MONÁRQUICA E FISCALIDADE}

Um dos temas mais recorrentes na historiografia sobre o Brasil Império é o da centralização monárquica. ${ }^{4}$ No plano político, esta centralização refletiu o triunfo do grupo vencedor das lutas travadas entre forças "centrípetas" e "centrífugas" nas duas primeiras décadas do período independente. A centralização política caracterizou o chamado "Regresso conservador" e teve como pontos marcantes a "interpretação" do Ato Adicional, em maio de 1840 - quando muitas das medidas descentralizadoras do período regencial foram revogadas -, o restabelecimento do Conselho de Estado (novembro de 1841) e a reforma do Código de Processo Penal (dezembro de 1841). ${ }^{5}$

A derrota das reivindicações "federalistas" não significou, porém, o fim das aspirações por maiores poderes (e recursos) para as províncias. Ao longo de todo o II Reinado, diversas vozes iriam se levantar contra aquilo que julgavam ser uma concentração excessiva de poderes nas mãos do governo central. O crítico mais eloqüiente da centralização monárquica foi Tavares Bastos que, em seu trabalho mais conhecido $(A$ Provincia, de 1870), detalhou o seu projeto liberal, federativo, descentralizador. O foco de seus ataques não era a Monarquia em si, mas a centralização do regime, para ele antidemocrática em sua essência. ${ }^{6}$

O contraponto ideológico de Tavares Bastos encontrava no Visconde do Uruguai o seu maior representante. Em duas influentes obras (Uruguai, 1865 e 2002), Paulino José Soares de Sousa expunha em detalhes as razões objetivas da centralização do poder no Império, cujas vantagens, pensava, em muito excediam os seus inconvenientes. ${ }^{7}$

Os recursos materiais que garantiam a centralização defendida por Uruguai e combatida por Tavares Bastos provinham de impostos arrecadados, em sua maior parte, das atividades de importação e exportação no Império. Tirando a questão relacionada à relativa fragilidade de uma base tributária fortemente dependente de receitas de

4 Para um excelente ensaio sobre as múltiplas facetas do debate em torno da centralização, ver Carvalho (1999).

5 Ver Bethell e Carvalho (1993) para um tratamento do conturbado período pós-Independência. Para uma cronologia acerca da experiência "republicana" do período regencial e da derrota daquele projeto político em favor das forças centralizadoras, ver Castro (1985). Em trabalho recente, Dolhnikoff (2005) diverge da visão predominante na literatura, ao argumentar que o poder político das províncias durante o II Reinado seria maior que tradicionalmente se supóe.

6 "A descentralização, que não é, pois, uma questão administrativa sómente, parece o fundamento e a condição de exito de quaesquer reformas politicas. É o systema federal a base solyda de instituições democraticas." (Tavares Bastos, 1935, p. 13).

7 Dentre as vantagens da centralização apontadas por Uruguai, estavam a administração das forças armadas, a integração territorial, a arbitragem de conflitos entre municípios e províncias, a garantia da uniformidade de impostos e a provisão de bens públicos, sob a forma de investimentos em "melhoramentos materiais". (Ver Uruguai, 2002, p. 439-40). Para um tratamento aprofundado das diferenças entre os pensamentos de Tavares Bastos e do Visconde de Uruguai em torno da questão da centralização, ver Ferreira (1999). 
comércio exterior, o cerne do problema fiscal no II Reinado envolvia a repartição destes recursos entre o governo central e as províncias.

O caráter centralizado desta repartição já se anunciava na Constituição de 1824, que no seu artigo 83 , parág. $3^{\circ}$, estabelecia que os Conselhos gerais das províncias eram proibidos de propor ou deliberar "sobre imposiçôes cuja iniciativa é da competência da Câmara dos Deputados." (Buescu, 1984). Porém, foi apenas na lei do orçamento de 1833-4 (de 24 de outubro de 1832) que as rendas públicas apareceram discriminadas pela primeira vez entre "Receita Geral" (cabendo ao governo central) e "Receita Provincial". As primeiras eram detalhadas na referida Lei e incluíam, entre outras, os direitos arrecadados nas alfândegas, sobre importações, exportações e baldeação; direitos de armazenagem, ancoragem e faróis; sisa de bens de raiz e vendas de próprios nacionais. ${ }^{8}$

Já quanto às províncias, o texto legal limitou-se a dizer, em seu Art. $83^{\circ}$, que pertenciam "todos os impostos ora existentes não comprehendidos na receita geral." Como se vê, uma falta de precisão cujo potencial para conflitos não seria diminuído pelo Ato Adicional, de 1834, que reformou a Constituição. Este substituiu os Conselhos Gerais pelas Assembléias Provinciais, que ficaram autorizadas, entre outras coisas, a legislar "sobre a fixação de despesas municipais e provinciais e os impostos a elas necessários", contanto que estes não prejudicassem as "imposiçôes gerais do Estado." Proibia-se, explicitamente, às Assembléias Provinciais legislarem sobre impostos de importação. (Deveza, 1985).

O resultado desta repartição legal dos recursos fiscais foi um sistema tributário complexo e com limitada capacidade de arrecadação fora das alfândegas. Nas palavras de Uruguai:

"O nosso systema de impostos eva, como ainda hoje, defeituoso. Não são elles filhos de um systema, mas, sem harmonia, creados e agglomerados pelo tempo, enxertados do systema velho portuguez do tempo colonial. Pouco avultados pelo tempo, e quase que exclusivamente as de importação e de exportação nos grandes mercados do littoral. Alguns nada produziam em certas provincias, principalmente centraes. A dispersão da população por immensas distancias tornava difficil a fiscalização e pouco produtiva a arrecadação."10

8 Art. $78^{\circ}$, Lei de 24 de outubro de 1832, in Brasil, Leis e Decretos (1874).

9 Na prática, as receitas provinciais incluíam, entre outras, contribuições de polícia, décima urbana, direitos de portagem e aguardente, venda de próprios provinciais, impostos de casas de leilão e moda etc. (Veiga Filho, 1906).

10 Uruguai (1865, Vol. I, p. 233). O ponto de Uruguai acerca da "pouca productiva arrecadação" ficará claro na discussão sobre o custo da arrecadação fiscal, na próxima seção. 
De fato, a arrecadação das províncias - em seu conjunto equivalente, em média, a 20\%-25\% das receitas do governo central - muitas vezes ficava aquém de seus gastos. ${ }^{11}$ Assim, de um total de 839 balanços no período 1840 a 1889, para os quais existem informações tanto de receita como de despesa provincial, foram constatados déficits em 421 casos (ou 50,2\%). Em oito províncias (de um total de 20) ocorreram déficits em mais da metade dos anos para os quais se dispõe de informações. ${ }^{12}$

Tais déficits ocorreram não obstante os esforços dos governos provinciais em aumentar suas receitas, muitas vezes recorrendo à cobrança de impostos e taxas vistos como abusivos por muitos contemporâneos, e que, não raro, extrapolavam sua competência tributária. Exemplo disto foram as inúmeras vezes em que as leis orçamentárias provinciais criavam impostos de importação sobre mercadorias estrangeiras, ou, ainda, sobre produtos exportados por províncias do interior, que buscavam os portos litorâneos.

Em virtude do caráter controverso - quando não abertamente inconstitucional - de muitas destas disposições provinciais, o governo imperial viu-se impelido a solicitar a opinião da Seção de Fazenda do Conselho de Estado, a quem caberia avaliar se as leis das províncias estavam em conformidade com a Constituição do Império. Assim, entre 1842 e 1867, das 881 consultas feitas àquela Seção, 226 (ou 25,7\%) versavam sobre a constitucionalidade de leis orçamentárias provinciais. ${ }^{13}$ De cada três consultas desta natureza, duas terminavam com a Seção opinando que as ditas leis provinciais deveriam ser suspensas pelo governo imperial, porém ouvindo-se, antes, a opinião da Assembléia Geral Legislativa. ${ }^{14}$

Enfrentando dificuldades para expandir a sua base de arrecadação, restaram às províncias duas alternativas, não excludentes entre si: endividar-se e contar com repasses de recursos do governo central. No primeiro caso, o endividamento do conjunto das 20 províncias do Império chegou a 36 mil contos em 1877, atingindo 61,8 mil contos em

11 As estatísticas fiscais provinciais são notoriamente precárias. Exemplo disto, de quatro fontes diferentes consultadas - a saber, os relatórios dos presidentes de províncias; Cavalcanti (1890); Brasil, Ministério da Agricultura (1914); e Breve Notícia (1887) -, raros foram os anos (e as províncias) em que houve a coincidência de dados de receita e despesa. Por esta razão, optou-se por basear o argumento que se segue em apenas uma fonte, mais completa, de dados - Brasil, Ministério da Agricultura, Indústria e Comércio (1914).

12 Foram elas: Alagoas, Ceará, Mato Grosso, Piauí, Paraná, Rio de Janeiro, Rio Grande do Sul e Sergipe. No caso específico do Mato Grosso, foram observados déficits em todos os 34 anos para os quais se dispõe de informações fiscais consolidadas, confirmando, na prática, o que dissera Uruguai a respeito da baixa arrecadação das províncias centrais (do interior).

13 A partir de 1867 e até o final do período imperial houve apenas uma consulta desta natureza, em 1870, referente à lei orçamentária da Bahia.

14 Imperiaes Resoluções (diversos volumes). A proporção de duas "rejeições" para uma "aceitação" foi obtida a partir da leitura de uma amostra aleatória de 10\% dessas consultas feitas à Seção de Fazenda do Conselho de Estado. 
$1887{ }^{15}$ Ainda assim, por cerca de 15 anos a partir do ano financeiro de $1839-40$ os governos provinciais receberiam transferências diretas do governo central, amparadas por lei de 22/10/1836. ${ }^{16}$ Ainda assim, tais transferências diretas - por mais que contrariassem pessoas como o Visconde de Uruguai - não foram suficientes para reverter o quadro generalizado de dificuldade financeira dos governos provinciais.

Para um observador atento sobre as questões financeiras do século XIX, Amaro Cavalcanti, na raiz dos problemas fiscais enfrentados pelas províncias - e das medidas freqüentemente inconstitucionais usadas para tentar remediá-los - encontrava-se um defeito de origem, qual seja, a "não-divisão das rendas" ao longo de todo o período imperial. ${ }^{17}$ Esta também era, em essência, a opinião de Tavares Bastos.

Escrevendo 20 anos antes de Amaro Cavalcanti, o autor de $A$ Provincia via como a principal causa da insuficiência das rendas das províncias as restrições ao poder provincial em matéria tributária. Em particular, Tavares Bastos criticava a interpretação geralmente dada às leis orçamentárias provinciais, nas quais diversos tipos de taxas incidentes sobre o consumo local ou mercadorias em trânsito eram confundidas com o imposto de importação - esse, sim, inequivocamente, afeto apenas às rendas gerais. A fim de remediar a penúria fiscal dos governos provinciais, o autor propunha que se assentasse a receita daquelas unidades administrativas na cobrança de impostos sobre a propriedade, segundo Cavalcanti base da riqueza dos cantóes suíços e dos estados do Meio-Oeste dos Estados Unidos. (Tavares Bastos, 1937, p. 332-3). Em outras palavras, para o autor a saúde financeira das províncias só seria restaurada caso se adaptasse ao Império o bem-sucedido modelo federativo daqueles dois países, onde governos subnacionais dispunham dos recursos para atender a demandas por gastos tipicamente locais, como o são os gastos em educação, por exemplo. Finalmente, Tavares Bastos sugeria a transferência, para as províncias, de verbas de receita típicas daquelas, mas que, pela legislação em vigor, eram carreadas para os cofres do governo central. ${ }^{18}$

15 Breve Notícia (Tabela N. 2). A dívida provincial em 1887 correspondia a cerca do dobro das receitas conjuntas das províncias naquele ano. A título de comparação, o passivo total do governo central (dívidas consolidadas interna e externa + dívida flutuante do Tesouro + notas do Tesouro em circulação) na mesma época era da ordem de 4,5 vezes as suas receitas anuais. (Goldsmith, 1986).

16 Esta lei estabelecia em seu art. $23^{\circ}$ que "o governo supprivia, desde já, pelos cofres da renda geral, o deficit das Provincias cujas rendas não chegassem para suas despezas, não excedendo porém o supprimento a differença que houvesse entre a despeza provincial fixada pela lei de 8/10/1833 e a renda que föra deixada a cada Provincia, pela lei de 31/10/1835." (Uruguai, 1865, volume I, p. 247).

17 "Se examinarmos as peças officiaes, os relatorios dos ministros, encontraremos que, há cerca de 50 annos, elles proprios reconhecem a necessidade urgente de fazer-se uma divisão criteriosa e de justiça entre as rendas do Tesouro Nacional e dos cofres provinciaes (...). Mas tudo isso não obstante, o imperio findou, sem que nada se tivesse realizado nesse sentido! E como as provincias não poderiam permanecer sem rendas de especie alguma, as suas assembleas provinciaes não só crearam contribuições exorbitantes das suas atribuiçôes constitucionais, como também outras, que, por seu caracter manifestadamente probibitivo prejudicaram o proprio funcionamento economico das mesmas entre si, reciprocamente." (Cavalcanti, 1890, p. 299).

18 A exemplo do imposto de transmissão de propriedade, o das indústrias e profissões, a taxa de escravos, o selo do papel fixo e proporcional etc. (Tavares Bastos, 1937, p. 336-7). 
Como se manifestava, na prática, a estrutura fiscal centralizada do Império? Segundo Tavares Bastos, na transferência líquida de recursos fiscais, do conjunto das 11 províncias do Norte (do Amazonas à Bahia) para o governo central. No Apêndice de $A$ Província, estas transferências líquidas - deduzidas as despesas com a manutenção do governo central e com o pagamento da dívida - foram estimadas em 7.000:000 em 1869-70, ou cerca de $20 \%$ das receitas gerais arrecadadas nas províncias meridionais naquele ano fiscal. Residiriam aí as dificuldades financeiras das províncias. Para o autor, obra da centralização monárquica.

Este último ponto - a transferência líquida de recursos fiscais entre as regiões do Império e o governo central - será examinado no que se segue. No restante do artigo, usa-se de metodologia semelhante à do trabalho de Tavares Bastos para medir a distribuição regional das receitas e despesas do governo imperial entre 1844 e 1889 .

\section{RECEITAS}

As características mais gerais da receita fiscal do governo durante o II Reinado são bastante conhecidas e já foram ressaltadas por diversos autores. ${ }^{19}$ De uma média de 18,9 mil contos no qüinqüênio 1840-1 a 1844-5, a receita bruta do governo imperial alcançou 141,7 mil contos, em média, nos últimos cinco anos do Império. ${ }^{20} \mathrm{Em}$ termos reais (i. é, ajustadas pela inflação), as receitas do governo central aumentaram pouco mais de $120 \%$ entre $1850-4$ e $1885-9 .^{21}$

As receitas do governo central representavam pouco mais de $80 \%$ das receitas de todos os níveis de governo em 1856-7, caindo para 76\% em 1885-6. ${ }^{22}$ As receitas provinciais, por sua vez, respondiam pela maior parte do restante, cabendo às receitas municipais de 3\% a 5\% do total. Goldsmith (1986, p. 71) estimou, ainda, que as receitas dos três níveis de governo representavam cerca de 10\% do PIB brasileiro em 1856 , com pequeno crescimento até o final do período imperial. ${ }^{23}$

19 Ver, por exemplo, Carreira (1980), Cavalcanti (1890) e, mais recentemente, Goldsmith (1986) e Abreu e Lago (2003). Salvo indicação em contrário, referências a receitas ou despesas do "governo imperial" dizem respeito ao governo central apenas, não incluindo as finanças provinciais e municipais.

20 Entre 1828 e 1887, o ano financeiro era contado de $1^{\circ}$ de julho a 30 de junho do ano seguinte. A coincidência do ano civil e do ano financeiro foi restabelecida em 1888, motivo pelo qual as estatísticas fiscais incluem, no ano financeiro de 1886-7, dados do $2^{\circ}$ semestre de 1887.

21 Valores deflacionados por índice de preços "composto", em Goldsmith (1986, p. 30-1).

22 Goldsmith (1986), citando dados de Carreira (1980).

23 Trata-se de proporção superior à dos Estados Unidos onde, segundo estimativas de Musgrave e Musgrave (1973), as receitas das três esferas de governo representavam cerca de 6,2\% do PIB em 1902 e, presumivelmente, uma proporção ainda menor em 1889. Em novo contraste com o caso do Brasil Império, a maior parte das receitas governamentais dos EUA naquele ano estavam a cargo das localidades, seguidas dos estados. 
Em termos de fontes de receita, o Império apresentava uma estrutura tributária típica da maior parte dos países à época, com forte dependência dos impostos cobrados sobre as importações e exportações de mercadorias. As receitas provenientes do comércio exterior (às quais se acrescentam as classificadas em Despacho Marítimo) responderam, em média, por $75 \%$ do total da arrecadação do governo central entre 1844-5 e 1889. As receitas de Interior, por seu turno, somavam, em média, pouco mais de $20 \%$ do total no II Reinado, sendo o restante completado pelas receitas ditas Extraordinárias, as chamadas Peculiares do Município (da Corte) (até 1866-7), e aquelas "Com Aplicação Especial". 24

Menos conhecida que essas características gerais da fiscalidade durante o Segundo Reinado é a sua dimensão regional. A coleta de dados nos Balanços da Receita e Despesa do Império desagregados em nível provincial permitiu que se calculasse a proporção das receitas arrecadadas no Norte e no Sul, tanto as totais (líquidas de operações de crédito interna e externa) como por cada categoria de receita. Os resultados são apresentados no Gráfico l e no Apêndice (Gráficos Al a A3).

\section{GRÁFICO 1 - DISTRIBUIÇÃO REGIONAL DA RECEITA LÍQUIDA DO GOVERNO CENTRAL, 1844-5 A 1889}

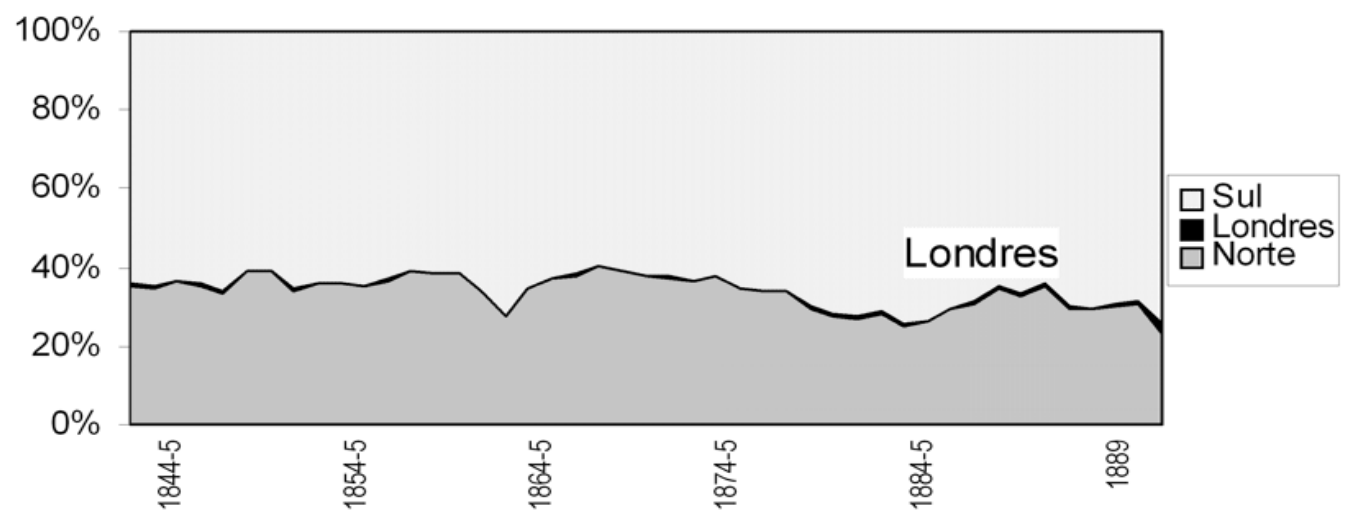

Como era de se esperar - dadas a primazia dos impostos cobrados sobre atividades de comércio exterior e o papel do porto do Rio de Janeiro como principal porta de entrada e de saída de mercadorias no Império -, a região Sul respondia pela maior parte da receita líquida do governo central no período sob exame.

24 As receitas de Interior provinham de impostos sobre indústrias e profissões, loterias, selo do papel, receitas dos Correios, das ferrovias etc. As Extraordinárias incluíam a contribuição para o Monte-Pio, indenizações e receitas eventuais. Já aquelas "Com Aplicação Especial" consistiam, a partir de 18712, da arrecadação de recursos para o Fundo de Emancipação (de escravos). (Ministério da Fazenda, Exposição, 1884). 
Em média, as províncias do Sul arrecadaram $64,5 \%$ das receitas líquidas do governo central entre $1844-5$ e 1889 , com os demais $35,5 \%$ sendo coletados no Norte e, marginalmente, na delegacia do Tesouro, em Londres. A arrecadação real per capita (a preços de 1870) diferiu muito entre as regiões: no Sul, de $9 \$ 300$ em 1854 ela subiu a $14 \$ 800$ em 1872, recuando para $13 \$ 000$ em 1889; no Norte, nos mesmos anos, ela passou de $4 \$ 800$ para $7 \$ 700$, caindo para $4 \$ 900 \mathrm{em} 1889$.

Norte e Sul (e, mais ainda, as diversas províncias que os compunham) também diferiam em relação ao custo de arrecadação. Este custo - medido como a razão entre os gastos para o funcionamento das repartições arrecadadoras ${ }^{25}$ e a receita do governo central coletada em cada região - foi, em média, de 6,2\% no Império como um todo. $^{26}$

\section{GRÁFICO 2 - CUSTO DE ARRECADAÇÃO DO GOVERNO CENTRAL, 1844-5 A 1889 (em \% da Receita Total)}

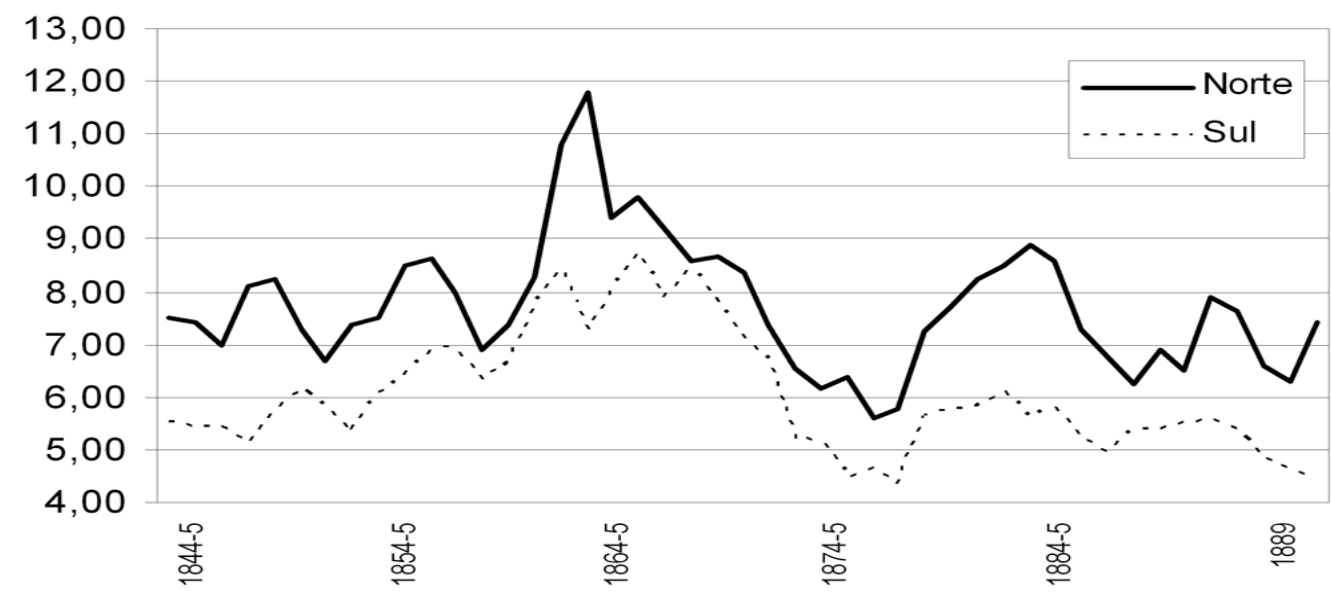

Como era de se esperar, o custo de arrecadação foi mais baixo no Sul $(5,7 \%$, em média) do que no Norte $(7,4 \%)$, tendo em vista os elevados custos de arrecadação em estaçôes fiscais no vasto interior do Norte, onde a base tributária era naturalmente baixa. $^{27}$

25 Vale dizer, a soma dos gastos para a manutenção do Tesouro Nacional, as tesourarias provinciais, alfândegas, consulados, mesas de renda e recebedorias.

26 À guisa de comparação, o custo de arrecadação no México foi estimado em 5,6\% em 1875-80, subindo para 9,7\% em 1890-5. (Ver Carmagnani, 1994).

27 Havia províncias, como o Amazonas e Goiás, onde o custo de arrecadação freqüentemente excedia o valor arrecadado. Tal situação decorria do fato de muitas das mercadorias importadas ali consumidas serem tributadas, respectivamente, nas alfândegas de Belém e do Rio de Janeiro, daí eliminando a principal fonte de arrecadação daquelas províncias do interior. 
Em termos das três principais categorias de receita (Importação, Interior e Exportação), a desagregação regional revela que entre 1844-5 e 1889 a região Norte contribuiu, em média, com uma parcela das receitas de Importação superior à sua participação nas receitas líquidas do governo central, vale dizer, 39,6\% (ver Gráfico Al, no Apêndice), testemunho da importância dos portos de Recife, Salvador, Belém e São Luís como pontos de entrada de mercadorias vindas do Exterior. No caso das receitas de Exportação, o peso do Norte foi equivalente à sua participação nas receitas - 35,5\% em média (Gráfico A3). Ainda no tocante à participação regional na receita fiscal do governo central, a diferença mais notável é dada pelas receitas de Interior, em que, em média, apenas $15,7 \%$ da arrecadação originavam-se nas províncias do Norte (Gráfico A2). Tal proporção foi superior a 25\%, em média, até meados dos anos 1860, decaindo a partir de então. Mais do que qualquer outra coisa, esta forte queda parece indicar a consolidação do Sul como centro econômico do Império (daí resultando uma base tributária crescente sobre a qual se arrecadavam as receitas de Interior), ao passo que a arrecadação no Norte se mantinha em bases "tradicionais", vale dizer, incidindo desproporcionalmente sobre atividades de comércio exterior.

\section{DESPESAS}

As despesas totais do governo imperial somaram, em média, 26,2 mil contos no qüinqüênio 1840-1 a 1844-5. Ao término do II Reinado, atingiriam 186,2 mil contos (média anual de 158,7 mil contos nos cinco últimos anos da Monarquia). Em termos reais, passaram de 47,6 mil contos (preços de 1870), em média, no período 1851-2 a 1855-6 para 110,7 mil contos, no último qüinqüênio do Império, perfazendo um crescimento de pouco mais de $110 \%$ no período. Tais despesas corresponderam a cerca de $8 \%$ do PIB na primeira metade da década de 1850 , chegando a $10,5 \%$ ao final do período monárquico, com um pico de cerca de $14,4 \%$ do PIB à época da Guerra do Paraguai. (Goldsmith, 1986, p. 71-2). Exceto em seis ocasiões (1845-6, 1846-7, 1852-3, 1856-7, 1871-2 e 1888) o governo central apresentou déficits em todos os anos financeiros entre 1840-1 e $1889 .{ }^{28}$ Estes déficits, por sua vez, foram financiados por uma combinação de endividamento interno e externo, bem como o recurso à emissão de moeda.

28 Para os republicanos, como Rui Barbosa, esta sucessão de déficits era prova inequívoca da incompetência administrativa da Monarquia. Já para o Visconde de Ouro Preto (último Presidente do Conselho de Ministros no Império e também Ministro da Fazenda) essa situação poderia ser explicada com base em quatro pontos: o endividamento externo associado ao acordo para o reconhecimento da Independência brasileira por Portugal; os acordos comerciais assinados com a Inglaterra, limitando a capacidade de o Brasil cobrar impostos alfandegários no nível que lhe interessasse; as despesas com a Guerra do Paraguai e os gastos com as secas no Norte. (Ver Visc. de Ouro Preto, "Finanças", in Década Republicana, 1986). 
A distribuição da despesa bruta entre os ministérios contemplou a Fazenda com a maior parcela do total (35\%, em média, no período 1844-5 a 1889), em virtude do peso representado pelos gastos com o serviço das dívidas interna e externa. Os ministérios militares (Marinha e Guerra) receberam, em média, 11,5\% e 19,9\%, respectivamente, no mesmo período. O Ministério da Agricultura e Obras Públicas, criado em 1860, passou a ocupar um lugar de destaque nas duas últimas décadas do II Reinado, sendo responsável pelas despesas associadas aos "melhoramentos materiais" - ferrovias, portos, engenhos centrais, colonização, companhias de navegação a vapor etc. - disputados intensamente pelas elites provinciais. ${ }^{29}$ Os recursos alocados àquele ministério corresponderam, em média, a 19\% do total entre 1860 e 1889. Os restantes 14\% foram distribuídos entre os Ministérios do Império, Justiça e Estrangeiros.

Em termos regionais, as despesas brutas foram majoritariamente realizadas na região Sul (68,8\%, em média, entre 1844-5 e 1889), ficando o Norte com 16,0\% e Londres com os restantes $15,2 \%$ em igual período. Este padrão de distribuição apresentou algumas variações quando se examinam os dados de cada um dos ministérios, como se vê na Tabela 1 .
TABELA 1 - DISTRIBUIÇÃO REGIONAL DAS DESPESAS BRUTAS DO GOVERNO IMPERIAL, POR MINISTÉRIO (média do periodo 1844-5 a $1889-\mathrm{em} \%)$

\begin{tabular}{lrrrr}
\hline Ministério & Norte & Sul & Londres & Total \\
\hline Império & 28,3 & 70,4 & 0,9 & 100,0 \\
Justiça & 36,0 & 62,1 & 0,2 & 100,0 \\
Estrangeiros & 1,3 & 54,6 & 43,6 & 100,0 \\
Marinha & 16,0 & 71,4 & 10,3 & 100,0 \\
Guerra & 17,7 & 74,9 & 2,3 & 100,0 \\
Agricultura /a & 13,0 & 69,9 & 17,0 & 100,0 \\
Fazenda & 11,5 & 60,5 & 27,5 & 100,0 \\
TOTAL & 16,0 & 68,8 & 15,2 & 100,0 \\
\hline
\end{tabular}

Fonte: Elaboração própria a partir de dados de Balanço da Receita e Despeza do Imperio, diversos números. /a média de 1860-1 a 1889.

Note-se que a primazia da região Sul como destino dos gastos do governo imperial se manteve em todos os ministérios no período em apreço, ainda que em menor grau nos casos do Ministério dos Estrangeiros e o da Fazenda. Em ambas as pastas, as despesas efetuadas em Londres tiveram um peso relevante - no último caso, em virtude dos gastos com o serviço da dívida externa. Destaca-se, ainda, a proporção relativamente maior, no Norte, dos gastos efetuados pelos Ministérios do Império e

29 A propósito das disputas em torno destes gastos, ver Carvalho (1996), Colson (1979), Graham (1977) e Mello (1999). 
da Justiça, pastas cujos desembolsos tendem a guardar maior relação com o número de habitantes da região. ${ }^{30}$

Uma forma alternativa de se analisar a distribuição regional dos gastos é por meio do exame, no Norte, Sul e Londres, das despesas de cada ministério (ver Tabela 2).

\begin{tabular}{|c|c|c|c|}
\hline Ministério/Região & Norte & Sul & Londres \\
\hline Império & 15,5 & 9,1 & 0,5 \\
\hline Justiça & 9,8 & 3,9 & 0,1 \\
\hline Estrangeiros & 0,1 & 0,9 & 3,2 \\
\hline Marinha & 11,6 & 12,2 & 7,8 \\
\hline Guerra & 22,1 & 22,1 & 3,0 \\
\hline Agricultura /a & 15,5 & 19,9 & 21,4 \\
\hline Fazenda & 25,5 & 31,8 & 64,0 \\
\hline TOTAL & 100,0 & 100,0 & 100,0 \\
\hline
\end{tabular}

Fonte: Elaboração própria a partir de dados de Balanço da Receita e Despeza do Imperio, diversos números. /a média de 1860-1 a 1889.

Vê-se, por exemplo, que as despesas do Ministério da Fazenda têm um peso maior no Sul que no Norte (31,8\%, em média, contra $25,5 \%)$, em virtude de o município da Corte concentrar a quase totalidade dos gastos com o serviço da dívida interna. É digna de nota, também, a importância relativamente maior dos gastos do Ministério da Agricultura na região Sul (19,9\% x 15,5\% no Norte). Conforme já salientado, as despesas desta pasta eram formadas, em sua maior parte, por investimentos em infra-estrutura, sendo, por essa razão, fonte de intensa disputa entre as províncias. $\mathrm{O}$ peso relativamente maior dos gastos deste ministério dentro da região Sul - região esta que, como visto na Tabela 1 , concentrou cerca de $2 / 3$ das despesas brutas entre 1844-5 e 1889 - já permite perceber um viés regional dos desembolsos em obras naquela região.

Em contrapartida, chama atenção o peso relativamente maior dos gastos do Ministério do Império no Norte (15,5\%, em média, contra 9,1\% no Sul). Tal diferença é explicada, em grande parte, pelas despesas referentes ao combate às secas que assolaram a região, provocando substancial elevação dos desembolsos daquele ministério em 1877-8, 1878-9 e 1889. Finalmente, nota-se a importância, em Londres, das despesas

30 A população das províncias do Norte passou de 4 milhões em 1854 para 5 milhões em 1872, chegando a 6,5 milhões em 1890. No Sul, nos mesmos anos, ela foi de 3,7 milhões, 5,1 milhões e 7,9 milhões. Em termos relativos, no Norte viviam 52\%, 49,8\% e 47,1\% da população do Império nestes anos. 
na pasta da Fazenda (pelos motivos já salientados) e na Agricultura, estas últimas envolvendo desembolsos relacionados às garantias de juros dadas às empresas de navegação a vapor, engenhos centrais e, sobretudo, estradas de ferro.

A análise empreendida até aqui esteve centrada no conceito de despesas totais (ou "brutas”), o que embute diversas distorções que terminam por ofuscar a percepção do "verdadeiro" padrão de distribuição regional dos gastos do governo imperial. Entre outras coisas, as despesas brutas incluem desembolsos com o serviço das dívidas interna e externa, bem como despesas associadas a "bens públicos” realizadas na Corte, ainda que estes bens fossem desfrutados pelo conjunto do Império. Após alguns ajustes - explicados em detalhe no Anexo Metodológico - chegou-se ao conceito de despesas líquidas e a uma nova repartição dos gastos entre o Norte e o Sul, como se vê no Gráfico 3. À região Sul coube, em média, 69,1\% das despesas líquidas do governo central entre 1844-5 e 1889 - proporção próxima à das despesas brutas, de $68,8 \%{ }^{31}$

\section{GRÁFICO 3 - DISTRIBUIÇÃO REGIONAL DAS DESPESAS LÍQUIDAS DO GOVERNO CENTRAL, 1844-5 A 1889}

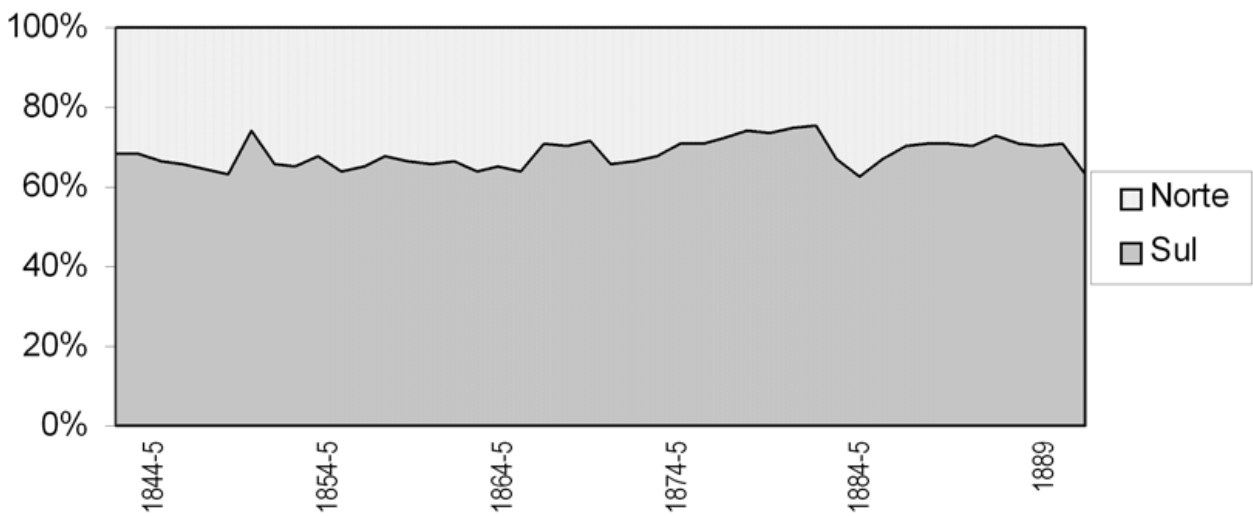

Em seguida, a distribuição regional das despesas líquidas foi comparada com a contribuição do Sul e do Norte para a receita líquida (de operações de crédito) do governo central, a cada ano. Com isso, foi possível chegar ao objetivo central do artigo, que é medir a contribuição relativa das duas regiões para as receitas e despesas do governo imperial. Para tanto, foi definido que se, por exemplo, a contribuição do Sul para a receita do governo central excedesse a sua participação nas despesas líquidas em determinado ano, aquela região efetuou uma transferência líquida de recursos para o

31 Em termos per capita (e a preços constantes de 1870), as despesas "líquidas" foram de 8\$200 no Sul e de $3 \$ 800$ no Norte em $1852 ; 12 \$ 100$ e $4 \$ 800$ em 1872 e de $9 \$ 500$ e $6 \$ 600$ em 1889 . 
governo central. ${ }^{32}$ Esta medida de transferência líquida segue, em espírito, a que fora proposta por Tavares Bastos, diferindo desta última no tratamento das despesas com dívidas. ${ }^{33}$ Os resultados são apresentados na Tabela Al, no Anexo, em que as transferências líquidas recebidas do governo central estão indicadas nas células hachuradas.

Como se vê, em 36 dos 44 anos fiscais examinados (i.é, em 80\% dos casos), a região Sul foi contemplada com despesas do governo imperial em proporção superior à contribuição daquela região para a receita total. Considerando-se a excepcionalidade dos gastos associados ao socorro prestado às vítimas das secas em 1877-8, 1878-9 e 1889 - que levaram a região Norte a receber transferências líquidas do governo central naqueles três anos - é possível afirmar que em condições "normais" o Norte efetuou transferências líquidas de recursos fiscais em 39 dos 44 anos, ou em 90\% dos casos, dando razão aos protestos de Tavares Bastos:

"Satisfaz o Norte, na parte que lhe compete, a todos os encargos da união.
Paga as despezas da administração geral nas suas provincias. Paga os serviços
que lhes interessam, vapores e estradas de ferro. Paga, além da que nellas se
effectua, a quota relativa da despeza com o exercito a armada. Paga a quóta
igualmente da representação nacional e da administração central. Paga os
tributos legados pelas guerras do Sul, soffre o papel-moeda, atura a divida pú-
blica...Ainda mais: remette ao Rio de Janeiro saldos liquidos, alguns milhares
de contos. Deve acaso, por cúmulo de males, suportar a centralisação?"34

A rerefência de Tavares Bastos aos gastos com "vapores e estradas de ferro" revela a correta percepção da importância das despesas em infra-estrutura física para o desenvolvimento econômico - fato, de resto, plenamente notado pelas elites contemporâneas. A fim de avaliar a importância destas despesas ao longo do II Reinado - bem como a sua distribuição regional - foi construída uma série histórica de desembolsos cuja natureza se assemelhava à de investimentos em capital fixo. Para tanto, definiuse uma categoria denominada "Obras", que inclui não apenas os gastos feitos pelos diversos ministérios sob esta rubrica (geralmente, construção e/ou ampliação de prédios públicos, fortalezas, alfândegas etc.), mas, também, despesas com irrigação, iluminação e esgotamento sanitário no município da Corte; gastos na construção (ou na garantia de juros, inclusive quando pagas em Londres) de estradas de rodagem, estradas de ferro, companhias de navegação a vapor, engenhos centrais, construção de

32 Alternativamente, se em determinado ano o Sul foi contemplado com despesas em montante superior à sua participação na receita do governo imperial, terá havido uma transferência líquida para aquela região, indicada pelas células hachuradas da Tabela Al, no Anexo.

33 Enquanto que em seus cálculos Tavares Bastos redistribuiu os gastos com o serviço da dívida entre o Norte e o Sul, aqui optou-se por exclú́-los do cômputo da despesa total.

34 Tavares Bastos (1937, p. 382-3). 
cais, faróis, instalação da rede de telégrafos, entre outros. A repartição regional destes gastos é apresentada no Gráfico 4.

\section{GRÁFICO 4 - DISTRIBUIÇÃO REGIONAL DOS GASTOS EM “OBRAS” NO IMPÉRIO, 1844-5 A 1889}

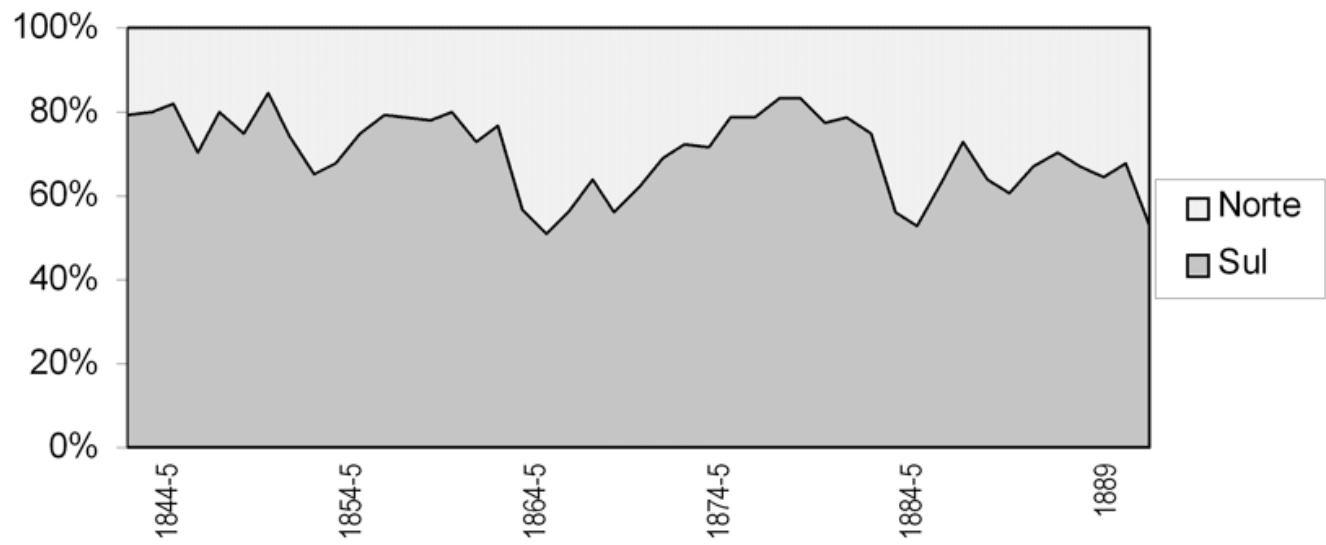

Os dados revelam que, de uma média de menos de 1.000 contos no qüinquiênio 1844-5 a 1848-9, os gastos em "Obras" cresceram exponencialmente ao longo do II Reinado, atingindo, no último qüinqüênio do Império, a média de 44,3 mil contos, ou pouco menos de $1 / 3$ das despesas totais. ${ }^{35} \mathrm{Em}$ termos reais, estes gastos multiplicaram-se por 10, em média, entre o período 1851-2 a 1854-5 e o último qüinqüênio da Monarquia.

Do ponto de vista de sua distribuição espacial, percebe-se que a região Sul foi contemplada com a maior parte dos gastos em "Obras" no período sob exame: em média, $66,4 \%$, cabendo os restantes $31,6 \%$ ao Norte. Em contrapartida, é interessante observar que o peso destes mesmos gastos no conjunto das despesas líquidas ${ }^{36}$ efetuadas em cada região foi maior no Norte $\left(24,6 \%\right.$, em média) do que no Sul $(18,5 \%) .{ }^{37}$

35 Essa proporção não difere muito daquela classificada por Graham como gastos em "novos setores", e que envolviam despesas em obras públicas, agricultura, transportes, infra-estrutura etc. (Ver Graham, 1977). Antes da criação do Ministério da Agricultura e Obras Públicas, em 1860, a maior parte das despesas de infra-estrutura era realizada pelo Ministério do Império e atingia montantes modestos. A criação daquele novo ministério, em 1860, reflete o aumento da demanda por (e oferta de) gastos daquele tipo.

36 Neste caso, adotou-se uma definição de despesas "líquidas" que inclui os gastos com o serviço das dívidas interna e externa, visto que, em muitos casos, estas dívidas foram contraídas justamente para financiar estas "obras".

37 Ressalta-se que este resultado é em parte explicado pela inclusão, no Norte, dos desembolsos com as despesas com as secas de 1878-9 e 1889. Ao mesmo tempo, a concentração, no Sul, dos desembolsos com o serviço da dívida interna, termina por "inflar" o denominador daquela razão, fazendo com que ela diminua. 


\section{GRÁFICO 5 - GASTO EM “OBRAS” COMO PROPORÇÃO DA DESPESA LÍQUIDA NAS REGIÕES, 1844-5 A 1889}

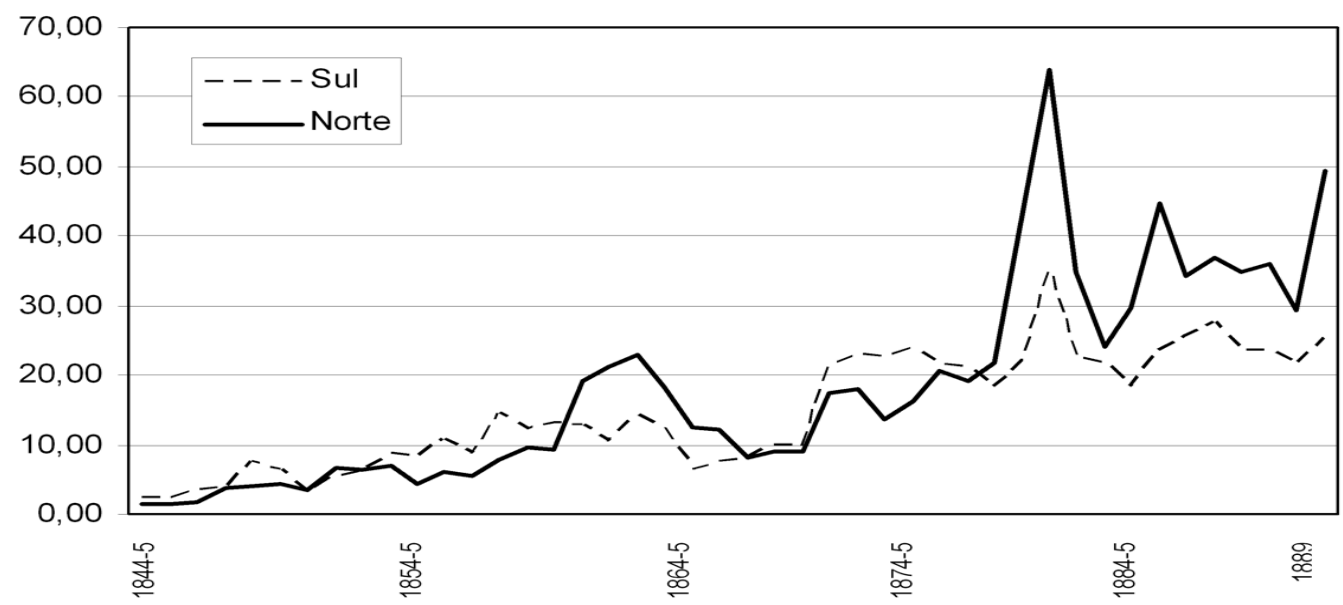

Da mesma forma que foi feito anteriormente - quando se examinaram as transferências regionais das despesas líquidas do governo imperial - é interessante comparar a relação entre os gastos em "Obras" nas duas regiôes com as respectivas contribuições para a receita líquida do governo central. Os resultados são apresentados na Tabela A2, no Anexo.

Nela se vê que em 31 dos 45 anos o Sul foi contemplado com despesas em "obras" em proporção superior à sua contribuição para as receitas líquidas do governo imperial. Embora se trate de frequiência inferior à que se verificou no caso das despesas "líquidas" - quando houve transferências líquidas positivas para o Sul em 36 anos - ainda assim aquela região saiu beneficiada na maior parte das vezes. Cabe notar, porém, que na última década da Monarquia o Norte recebeu transferências líquidas de recursos para "Obras" em oito anos fiscais, o que pode estar a indicar o esforço do governo central de atender às demandas por "melhoramentos materiais" daquela região, como forma de salvar o regime. ${ }^{38}$

O crescimento mais que proporcional dos desembolsos em "melhoramentos materiais" no Norte fica mais claro quando se examinam as despesas per capita (a preços de 1870) nas rubricas classificadas como "Obras": de um montante de 293 réis em 1854, estes gastos aumentaram para 903 réis em 1872 e atingiram 3\$760 em 1889 (caso sejam excluídos os gastos com a Seca neste último ano, os desembolsos per capita caem para 1\$609). Em contrapartida, no Sul, os gastos per capita nestas mesmas rubricas saíram

38 Sobre este ponto, ver Colson (1979). 
de 803 réis em 1854 para $3 \$ 840$ em 1872, caindo para $3 \$ 499$ em 1889 (3\$218 sem a Seca).

Dois tipos de gastos explicam, em boa medida, o padrão de desembolsos de recursos para "Obras", enviesado a favor do Sul: os relacionados à construção e ampliação da E. F. D. Pedro II e aquelas despesas realizadas em obras de infra-estrutura no município da Corte, nas áreas de abastecimento de água, encanamento de rios, esgotamento sanitário e iluminação pública. Já na região Norte predominavam os gastos em ferrovias e com a subvenção das companhias de navegação a vapor. Os desembolsos do governo central no combate às secas na região - aqui classificados como gastos em "Obras" - estão por trás das elevadas transferências positivas para o Norte em 1877-8, 1878-9 e 1889. Caso estas despesas sejam excluídas do cômputo dos gastos em "Obras", as transferências a partir do Norte tornam-se positivas em 1877-8 (isto é, a região recebe proporcionalmente menos do que a sua contribuição para a receita líquida do governo central naquele ano) e se reduzem nos outros dois anos (embora a região ainda receba recursos liquidamente).

Até aqui a análise das transferências de recursos fiscais entre as duas regiões e o governo central esteve baseada na comparação das contribuições relativas (porcentuais) do Norte e do Sul para a receita e despesas líquidas. Deve-se ter em mente, porém, que estas participações porcentuais se referem a montantes absolutos intrinsecamente diferentes, vale dizer, receitas e despesas nunca coincidiram, sendo o déficit quase sempre a regra. Neste sentido, um exercício complementar envolve calcular os valores absolutos das transferências fiscais havidas entre as duas regiões e o governo imperial. Em outras palavras, estimar os valores monetários efetivamente arrecadados e despendidos no Norte e no Sul.

Para tanto, procedeu-se, primeiramente, à transformação das séries de receitas e despesas líquidas - calculadas anteriormente para os anos fiscais - em séries referentes aos anos-calendário. ${ }^{39}$ Em seguida, deflacionou-se a série original (calculada a preços correntes), por meio do índice de preços de Goldsmith (1986, p. 30-1), chegando-se, assim, a uma série a preços constantes de $1870 .{ }^{40}$ Isto torna possível a comparação ao longo de um período de 40 anos e na presença de inflação. Os resultados encontramse na Tabela A3, no Anexo.

Como se vê, em diversos anos (notadamente durante a Guerra do Paraguai, entre 1865 e 1870) tanto o Norte como o Sul receberam do governo central recursos em

39 Na prática, a média aritmética de dois anos fiscais consecutivos. Por exemplo, a receita de 1860 equivale à média entre a receita de 1859-60 e 1860-1.

40 A série de receitas e despesas daí resultante se inicia em 1852, devido à ausência de informaçóes fiscais para o ano fiscal de 1850-1, bem como pelo fato de a série do índice de preços de Goldsmith iniciar-se em 1850. 
montante superior às receitas líquidas ali arrecadadas (assinalados nas células hachuradas, indicando que as despesas do governo central naquela região superam as receitas líquidas ali arrecadadas). Ainda que paradoxal à primeira vista, tal resultado é logicamente possível. De fato, embora as receitas líquidas não incluam recursos obtidos em operações de crédito (empréstimos) ou via emissão monetária - largamente utilizada durante o conflito do Paraguai - as despesas, sim, envolvem gastos financiados desta forma.

Os dados da Tabela A3 revelam, também, uma relativa igualdade no número de anos em que cada região enviou recursos ao governo central em montante superior às despesas ali realizadas: 26 no Sul, contra 28 no Norte (de um total de 38 anos). Contudo - e isso é crucial -, a soma do excesso de receitas arrecadadas sobre despesas realizadas localmente - um indicador mais fidedigno da transferência de recursos líquidos para o governo central - revela que enquanto o Sul transferiu liquidamente, no período 1852-1889, 74,5 mil contos (a preços de 1870) para o governo central, a transferência equivalente a partir do Norte foi de 119,3 mil contos. Em termos do esforço contributivo de cada região, isto é, das receitas líquidas arrecadadas, os resultados são ainda mais eloqüentes: as transferências líquidas realizadas pelo Sul para o governo central somaram $3,3 \%$ das receitas arrecadadas naquela região, ao passo que a contribuição líquida das províncias do Norte equivaleu a expressivos $11 \%$ das receitas centrais ali coletadas. ${ }^{41}$

Em suma, o Norte, na prática, contribui desproporcionalmente para o custeio do governo central, tal como perceberam diversos contemporâneos, dentre os quais Tavares Bastos.

\section{CONCLUSÕES}

O exame da origem das receitas brutas do governo imperial no II Reinado, desagregada por região, confirmou o predomínio das províncias do Sul. Em termos per capita, a arrecadação da região Sul equivale, em média, em 1854, 1872 e 1889, ao dobro das receitas levantadas pelo Norte. Tal predomínio também foi observado ao se examinar a origem regional da receita, por principais fontes de impostos, fenômeno que se mostrou mais visível no caso das rendas do Interior, para os quais o Sul contribuiu, em média, com cerca de $85 \%$ do total. Conforme se esperava, o custo de arrecadação no Sul também se mostrou inferior ao do Norte: $5,7 \%$ e $7,4 \%$, respectivamente, das receitas do governo central arrecadadas em cada região.

41 Cabe notar que, tendo em vista os ajustes detalhados no Apêndice, é perfeitamente possível que tanto o Norte como Sul realizem transferências líquidas de recursos fiscais para o governo central (localizado no Sul), dado que parte destes recursos era gasta no pagamento de dívidas contraídas doméstica e internacionalmente. 
Com relação às despesas brutas, $2 / 3$, em média, foram realizadas no Sul e o restante distribuído, grosso modo, meio a meio entre o Norte e Londres. O predomínio do Sul foi verificado em todos os ministérios, ainda que em menor grau no caso dos Ministérios da Fazenda e Estrangeiro, onde as despesas realizadas em Londres eram consideráveis. Na importante pasta da Agricultura, por sua vez, as despesas foram feitas mais que proporcionalmente no Sul, o que dava origem a conflitos com as elites agrárias do Norte.

Após os ajustes detalhados no Anexo Metodológico, chegou-se ao conceito de despesas líquidas, também majoritariamente realizadas na região Sul. Com base na série assim obtida, foi possível desenvolver aquele que era o objetivo central do artigo, qual seja, medir a contribuição relativa de cada região para a receita e despesa (líquidas) do governo central. Os resultados - exibidos na Tabela Al, no Apêndice - mostram que em 36 dos 44 casos o Sul foi beneficiário do que se definiu como transferências líquidas de recursos fiscais do governo central.

Este viés também se verificou no caso das despesas em infra-estrutura física. A compilação de uma série de gastos em "Obras” permitiu constatar - quando confrontada com a origem regional das receitas - que o Sul também foi desproporcionalmente beneficiado com este importante item do gasto público. Neste caso, porém, o número de anos em que houve transferências líquidas do governo central para o Sul foi menor (31 - ou 32, caso sejam excluídas as despesas com o auxílio às vítimas das secas dos gastos em "Obras”). Além disso, verificou-se que na década final do Império as transferências líquidas se deram, majoritariamente, no sentido inverso, isto é, para o Norte, numa aparente "concessão" do governo imperial às demandas das elites agrárias das províncias setentrionais por investimentos em infra-estrutura econômica.

Em um refinamento da análise, ambos os exercícios foram complementados com estimativa do montante absoluto de transferências de recursos fiscais efetuadas entre cada região e o governo central. O resultado a que se chegou - com transferências líquidas do Norte equivalentes a $11 \%$ das receitas arrecadadas naquela região, contra $3,3 \%$ no caso do Sul - reforça a imagem de um viés na estrutura fiscal da época, que prejudicava desproporcionalmente a região Norte.

Para terminar, é oportuno ressaltar que existe uma clara dimensão de "economia política” do gasto público que não foi tratada aqui. Especificamente, cabe se perguntar por que é que o Norte - que, ao longo do período imperial, sempre manteve uma representação na Assembléia Legislativa superior ao Sul (no último parlamento do Império, o de 1886-9, as províncias do Norte elegeram 68 deputados, contra 57 do Sul) - , não foi capaz de direcionar parcela maior dos gastos do governo central para aquela região. A resposta óbvia é que não havia uma região "Norte” homogênea, coe- 
sa, cuja bancada parlamentar votasse em bloco a lei do Orçamento (ou qualquer outra lei). Amaro Cavalcanti, uma vez mais, percebia com clareza a natureza do problema federativo no Império. O autor protestava veementemente contra a existência de províncias de " 1 a" e de " 2 " classe no Império. (Cavalcanti, 1890, p. 296). E notava que, entre as do primeiro grupo, encontravam-se duas províncias do Norte: a Bahia, ou Pernambuco. Esta última, inclusive, se aproveitava da dependência que tinha o Rio Grande do Norte (estado de origem de Amaro Cavalcanti) em relação ao porto do Recife, para cobrar-lhe impostos abusivos sobre mercadorias em trânsito e destinadas ao Rio Grande. Eis aqui um possível ponto de partida para pesquisas futuras sobre a questão fiscal e o federalismo no Império, baseadas no estudo dos padrões regionais (ou provinciais) de votação das leis do orçamento.

\section{ANEXO METODOLÓGICO: DA DESPESA BRUTA À DESPESA LÍQUIDA}

A desagregação regional das despesas do governo imperial exige um cuidado maior que o envolvido no exame das receitas. Primeiramente, deve-se ter presente que, ao contrário das receitas, os gastos do governo central não se davam apenas no Brasil, mas também em Londres, onde, além do pagamento do serviço da dívida externa, eram liquidadas compras de equipamentos, navios etc. para o Império. Uma segunda dificuldade surge do fato de no município da Corte (Rio de Janeiro) serem efetuadas diversas despesas que devem ser consideradas como "bens nacionais", mas que, por razões administrativas, eram contabilmente (e na prática) lançadas na capital. Por fim, também no Rio de Janeiro eram feitas despesas referentes a gastos que diziam respeito claramente a alguma província do Império - e não ao município da Corte - constituindo o que se pode chamar de despesas com um "bem provincial".

Sendo assim, antes de se proceder ao cálculo da distribuição provincial (e, a partir dela, regional) das despesas, foi necessário, partindo-se dos valores da Despesa Bruta constantes dos relatórios oficiais, efetuar diversos ajustes até que se chegasse ao conceito de Despesa Líquida - esta, sim, objeto de análise com desagregação regional.

Um primeiro ajuste na série de Despesa Bruta envolveu excluir todos os gastos referentes às dívidas interna e externa. ${ }^{42}$ A lógica por trás desta decisão é a de que gastos com dívida diferem de outros gastos, por refletirem o pagamento pelo capital de terceiros, capital este originalmente gasto em algo já contabilizado no passado como uma des-

42 Na prática, para cada província do Império e Londres foram subtraídos da Despesa Bruta gastos eventuais com o pagamento de juros e amortização da dívida externa, da dívida interna consolidada, da dívida interna ainda não consolidada, da dívida flutuante (bilhetes do Tesouro), do empréstimo nacional de 1868 (levantado para ajudar no financiamento da campanha militar no Paraguai), do empréstimo do Cofre dos Órfãos e das Caixas Econômicas. 
pesa de alguma natureza (obras, ferrovias, serviços etc.). O resultado dessa primeira "depuração" foi a obtenção de uma série denominada "Despesa ex-Dívidas".

O segundo passo consistiu em efetuar um levantamento minucioso, e para cada ano, de tudo o que pudesse ser considerado um "bem nacional". Para tanto, utilizou-se uma definição semelhante à proposta por Tavares Bastos (1937) e que envolveu considerar como "bens nacionais" os gastos com a manutenção da Família Imperial, com o Poder Legislativo, o Judiciário (em suas instâncias superiores), o Conselho de Estado, a Tipografia Nacional, as secretarias de todos os ministérios, a totalidade dos gastos do Ministério dos Estrangeiros, o pagamento de diferenças de câmbio e diversas outras rubricas (ou partes delas) espalhadas por todos os ministérios. Como se pode imaginar, a escolha de o que efetivamente constitui um "bem nacional" envolve um forte grau de arbitrariedade. Mesmo assim, o resultado final não diferiu em muito do obtido por Tavares de Bastos para o ano de 1866-7. No período 1844-5 a 1889, estes gastos foram da ordem de 20\% das Despesas Brutas totais (ou 36\% das despesas efetuadas no município da Corte). Estes "gastos nacionais" foram, em seguida, redistribuídos da Corte (onde originalmente se incluíam, por terem sido efetuados no Rio de Janeiro) para as duas regiões, segundo a parcela de cada uma delas na Receita líquida do governo central a cada ano. Com esse critério, procurou-se maior "neutralidade" no rateio que, caso fosse baseado em população ou em divisão "salomônica” (meio a meio), levaria a uma superestimação do montante de gastos efetuados no Norte.

Além destes "bens nacionais", em alguns casos lançavam-se despesas no município da Corte referentes a gastos no Norte com a construção de ferrovias, garantias de juros a companhias de navegação a vapor, combate às secas etc. Ainda que criticável, para efeito do cômputo da distribuição regional deste tipo de gasto tomou-se a decisão de realocar integralmente estes "bens provinciais" à região Norte. Terminado este ajuste chegou-se a nova série de Despesas, agora líquidas de dívidas e com a redistribuição dos bens nacionais e provinciais.

O passo final consistiu em se redistribuir entre o Norte e o Sul os gastos que ainda restavam alocados a Londres após a "depuração" das despesas com dívidas. Novamente, o critério de repartição deste "resíduo" foi a contribuição de cada região para a Receita líquida do governo central a cada ano. À série final obtida após todos esses ajustes foi dado o nome de "Despesa Líquida".

Tem-se, esquematicamente, que:

Despesas Líquidas $=$ Despesas Brutas - Dívidas + Redistribuição (entre o Norte e Sul) de gastos em "bens nacionais", "bens provinciais" e "resíduo" de despesas efetuadas em Londres 


\section{TABELA AI - TRANSFERENCIAS LÍQUIDAS ENTRE AS REGIÕES E O GOVERNO CENTRAL, 1844-5 A 1889}

\begin{tabular}{|c|c|c|c|c|c|}
\hline Ano & Norte & Sul & Ano & Norte & Sul \\
\hline $1844-5$ & 3,7 & $-4,3$ & $1867-8$ & 3,4 & $-3,7$ \\
\hline $1845-6$ & 2,9 & $-3,2$ & $1868-9$ & 2,5 & $-2,7$ \\
\hline $1846-7$ & 3,3 & $-3,5$ & $1869-70$ & 5,1 & $-5,2$ \\
\hline $1847-8$ & 1,2 & $-1,5$ & $1870-1$ & 5,7 & $-5,7$ \\
\hline $1848-9$ & $-1,7$ & 1,6 & $1871-2$ & 5,4 & $-5,4$ \\
\hline $1849-50$ & 2,1 & $-2,2$ & $1872-3$ & 6,1 & $-6,1$ \\
\hline $1850-1$ & n.d. & n.d. & $1873-4$ & 4,2 & $-4,8$ \\
\hline $1851-2$ & 8,1 & $-8,6$ & $1874-5$ & 1,1 & $-1,6$ \\
\hline $1852-3$ & 1,6 & $-1,9$ & $1875-6$ & 2,2 & $-2,5$ \\
\hline $1853-4$ & 1,2 & $-1,2$ & $1876-7$ & 4,0 & $-4,1$ \\
\hline $1854-5$ & 2,9 & $-3,1$ & $1877-8$ & $-7,8$ & 7,3 \\
\hline $1855-6$ & 0,9 & $-1,3$ & $1878-9$ & $-10,9$ & 10,9 \\
\hline $1856-7$ & 4,1 & $-4,3$ & $1879-80$ & $-3,1$ & 2,9 \\
\hline $1857-8$ & 6,5 & $-6,7$ & $1880-1$ & 1,7 & $-1,9$ \\
\hline $1858-9$ & 5,3 & $-5,4$ & $1881-2$ & 5,2 & $-5,7$ \\
\hline $1859-60$ & $-0,4$ & 0,4 & $1882-3$ & 3,9 & $-4,5$ \\
\hline $1860-1$ & $-5,8$ & 5,7 & $1883-4$ & 5,7 & $-6,6$ \\
\hline $1861-2$ & $-1,2$ & 1,2 & $1884-5$ & 2,1 & $-2,6$ \\
\hline $1862-3$ & 2,3 & $-2,5$ & $1885-6$ & 0,1 & $-0,4$ \\
\hline $1863-4$ & 2,0 & $-2,4$ & $1886-7$ & 0,5 & $-1,4$ \\
\hline $1864-5$ & 12,5 & $-12,5$ & 1888 & 1,9 & $-2,6$ \\
\hline $1865-6$ & 9,2 & $-9,3$ & 1889 & $-13,2$ & 11,0 \\
\hline $1866-7$ & 9,3 & $-9,5$ & & & \\
\hline
\end{tabular}

Fonte: Elaboração própria a partir de dados de Balanço da Receita e Despeza do Imperio, diversos números.

Obs: Transferências líquidas são definidas como a diferença entre a contribuição da região para a receita líquida (de operações de crédito) do governo imperial e sua participação porcentual nas despesas "líquidas" totais naquele ano. 
TABELA A2 - GASTOS EM “OBRAS": TRANSFERENCIAS LÍQUIDAS ENTRE AS REGIÓES E O GOVERNO CENTRAL, 1844-5 A 1889

\begin{tabular}{lrrlrr}
\hline Ano & Norte & Sul & Ano & Norte & Sul \\
\hline $1844-5$ & 14,7 & $-15,3$ & $1867-8$ & 6,2 & $-6,4$ \\
$1845-6$ & 15,1 & $-15,4$ & $1868-9$ & 8,4 & $-8,5$ \\
$1846-7$ & 18,5 & $-18,7$ & $1869-70$ & 9,1 & $-9,2$ \\
$1847-8$ & 5,7 & $-6,0$ & $1870-1$ & 13,3 & $-13,3$ \\
$1848-9$ & 13,8 & $-13,9$ & $1871-2$ & 13,2 & $-13,2$ \\
$1849-50$ & 13,7 & $-13,8$ & $1872-3$ & 17,0 & $-17,0$ \\
$1850-1$ & 23,8 & $-24,2$ & $1873-4$ & 12,9 & $-13,5$ \\
$1851-2$ & 8,2 & $-8,7$ & $1874-5$ & 5,1 & $-5,6$ \\
$1852-3$ & 0,8 & $-1,1$ & $1875-6$ & 6,2 & $-6,4$ \\
$1853-4$ & 3,5 & $-3,6$ & $1876-7$ & 3,6 & $-3,7$ \\
$1854-5$ & 9,9 & $-10,1$ & $1877-8$ & $-18,9$ & 18,3 \\
$1855-6$ & 16,3 & $-16,7$ & $1878-3$ & $-20,6$ & 20,6 \\
$1856-7$ & 17,9 & $-18,2$ & $1879-80$ & $-7,1$ & 7,0 \\
$1857-8$ & 16,5 & $-16,7$ & $1880-1$ & 3,7 & $-4,0$ \\
$1858-9$ & 18,8 & $-18,9$ & $1881-2$ & $-1,5$ & 1,0 \\
$1859-60$ & 7,0 & $-7,1$ & $1882-3$ & $-6,6$ & 6,0 \\
$1860-1$ & 4,7 & $-4,7$ & $1883-4$ & 2,4 & $-3,3$ \\
$1861-2$ & $-8,2$ & 8,2 & $1884-5$ & $-0,2$ & $-0,3$ \\
$1862-3$ & $-12,0$ & 11,8 & $1885-6$ & $-3,6$ & 3,2 \\
$1863-4$ & $-6,1$ & 5,7 & $1886-7$ & $-5,2$ & 4,3 \\
$1864-5$ & 5,6 & $-5,7$ & 1888 & $-1,7$ & 1,0 \\
$1865-6$ & $-5,2$ & 5,1 & 1889 & $-23,6$ & 21,4 \\
$1866-7$ & $-0,3$ & 0,1 & & & \\
\hline
\end{tabular}

Fonte: Elaboração própria a partir de dados de Balanço da Receita e Despeza do Imperio, diversos números.

Obs: Transferências líquidas são definidas como a diferença entre a contribuição da região para a receita líquida (de operações de crédito) do governo imperial e sua participação porcentual nas despesas "em Obras" naquele ano. 


\section{TABELA A3 - VALOR DAS TRANSFERENCIAS LÍQUIDAS DE RECURSOS FISCAIS ENTRE AS REGIÓES E O GOVERNO IMPERIAL, 1852- 1889 (em 1.000 contos de réis)}

\begin{tabular}{|c|c|c|c|c|}
\hline & \multicolumn{2}{|c|}{$\begin{array}{l}\text { Receitas - Despesas } \\
\text { (a preços correntes) }\end{array}$} & \multicolumn{2}{|c|}{$\begin{array}{l}\text { Receitas - Despesas } \\
\text { (a preços de 1870) * }\end{array}$} \\
\hline & Norte & Sul & Norte & Sul \\
\hline 1852 & $3.533,1$ & $1.555,4$ & $6.242,2$ & $2.748,0$ \\
\hline 1853 & $3.454,0$ & $5.140,1$ & $5.643,8$ & $8.398,8$ \\
\hline 1854 & $2.474,1$ & $2.675,6$ & $3.760,0$ & $4.066,3$ \\
\hline 1855 & $2.313,6$ & $2.279,3$ & $3.309,8$ & $3.260,9$ \\
\hline 1856 & $4.849,0$ & $5.462,0$ & $6.615,3$ & $7.451,5$ \\
\hline 1857 & $6.101,1$ & $3.983,7$ & $7.964,9$ & $5.200,7$ \\
\hline 1858 & $4.024,4$ & $-495,4$ & $5.512,9$ & $-678,6$ \\
\hline 1859 & $1.353,4$ & $-767,6$ & $1.811,7$ & $-1.027,6$ \\
\hline 1860 & $-536,5$ & $3.486,2$ & $-704,9$ & $4.581,1$ \\
\hline 1861 & 959,4 & $6.813,0$ & $1.272,4$ & $9.035,9$ \\
\hline 1862 & $1.760,5$ & $2.443,0$ & $2.289,3$ & $3.176,8$ \\
\hline 1863 & $2.424,0$ & $1.132,1$ & $3.143,9$ & $1.468,3$ \\
\hline 1864 & $2.636,5$ & $-7.155,1$ & $3.227,1$ & $-8.757,8$ \\
\hline 1865 & $-3.863,8$ & $-28.922,9$ & $-4.441,2$ & $-33.244,7$ \\
\hline 1866 & $-7.257,8$ & $-37.173,4$ & $-8.073,2$ & $-41.349,7$ \\
\hline 1867 & $-13.243,2$ & $-41.541,4$ & $-14.649,5$ & $-45.952,9$ \\
\hline 1868 & $-15.705,0$ & $-37.740,0$ & $-15.705,0$ & $-37.740,0$ \\
\hline 1869 & $-6.282,3$ & $-23.248,2$ & $-6.220,1$ & $-23.018,0$ \\
\hline 1870 & $4.949,9$ & $-4.233,0$ & $4.949,9$ & $-4.233,0$ \\
\hline 1871 & $14.721,1$ & $16.408,7$ & $15.350,4$ & $17.110,3$ \\
\hline 1872 & $14.394,1$ & $13.662,9$ & $14.793,5$ & $14.042,1$ \\
\hline 1873 & $9.295,0$ & $4.372,5$ & $9.184,8$ & $4.320,7$ \\
\hline 1874 & $5.456,5$ & $4.468,8$ & $5.418,5$ & $4.437,7$ \\
\hline 1875 & $3.587,8$ & $3.257,9$ & $3.613,1$ & $3.280,8$ \\
\hline 1876 & $3.226,6$ & $-2.885,5$ & $3.114,5$ & $-2.785,2$ \\
\hline 1877 & $-3.343,9$ & $-87,9$ & $-3.125,1$ & $-82,1$ \\
\hline 1878 & $-17.371,4$ & $-1.649,7$ & $-16.465,8$ & $-1.563,7$ \\
\hline 1879 & $-12.009,3$ & $1.683,2$ & $-11.099,2$ & $1.555,7$ \\
\hline 1880 & $6.181,2$ & $16.409,1$ & $5.624,4$ & $14.930,9$ \\
\hline 1881 & $13.831,3$ & $17.546,1$ & $12.866,4$ & $16.321,9$ \\
\hline 1882 & $13.736,4$ & $12.335,8$ & $13.736,4$ & $12.335,8$ \\
\hline 1883 & $12.425,8$ & $7.578,5$ & $11.800,4$ & $7.197,0$ \\
\hline 1884 & $9.223,1$ & $4.288,8$ & $9.024,6$ & $4.196,5$ \\
\hline 1885 & $6.077,3$ & $9.811,4$ & $5.606,4$ & $9.051,1$ \\
\hline 1886 & $13.001,6$ & $27.928,7$ & $12.347,2$ & $26.523,0$ \\
\hline 1887 & $18.167,9$ & $35.745,6$ & $16.426,7$ & $32.319,7$ \\
\hline 1888 & $17.483,0$ & $32.057,3$ & $15.980,8$ & $29.302,8$ \\
\hline 1889 & $-12.753,0$ & $32.354,4$ & $-10.872,1$ & $27.582,6$ \\
\hline
\end{tabular}

Fonte: Elaboração própria a partir de dados do Balanço da Receita e Despesa do Império, diversos números.

* Valores deflacionados por índice de preços "composto", em Goldsmith (1986). 
GRÁFICO AI - DIST. REGIONAL DA RECEITA DO IMPOSTO DE IMPORTAÇÃO, 1844-5 A 1889

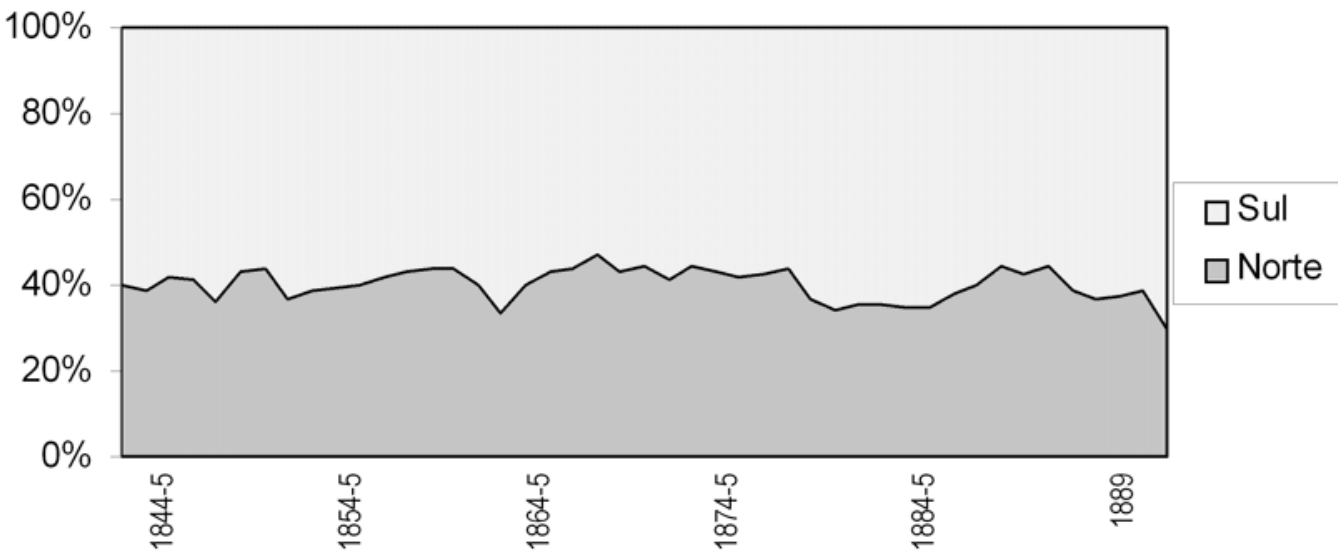

GRÁFICO A2 - DIST. REGIONAL DA RECEITA DO IMPOSTO DE INTERIOR, 1844-5 A 1889

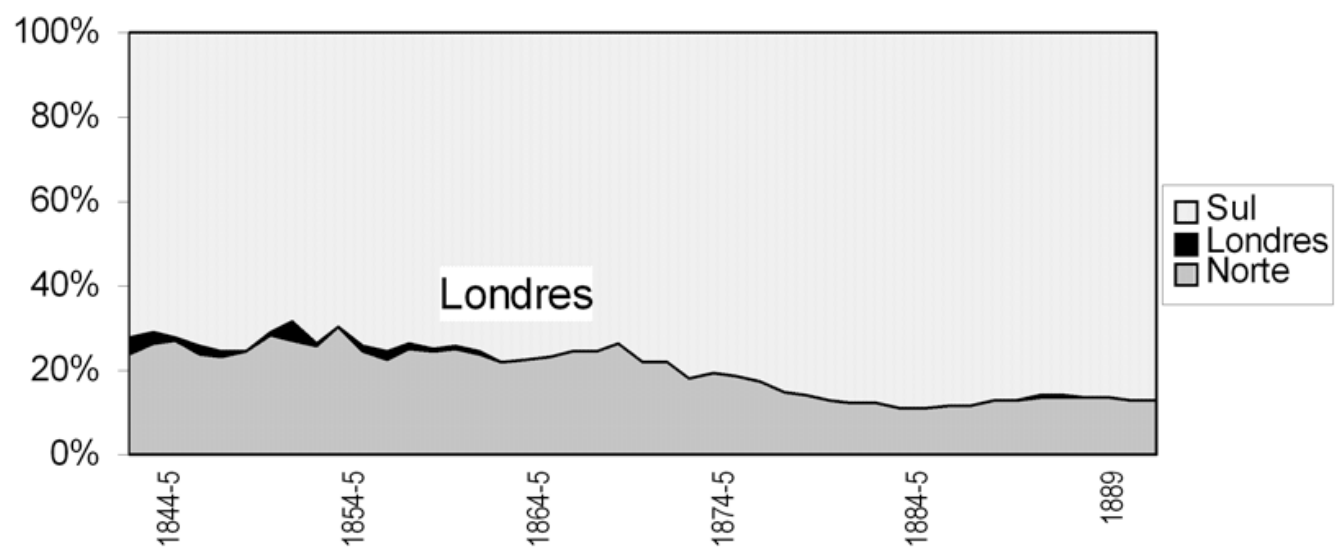


GRÁFICO A3 - DIST. REGIONAL DA RECEITA DO IMPOSTO DE EXPORTAÇÃO, 1844-5 A 1889

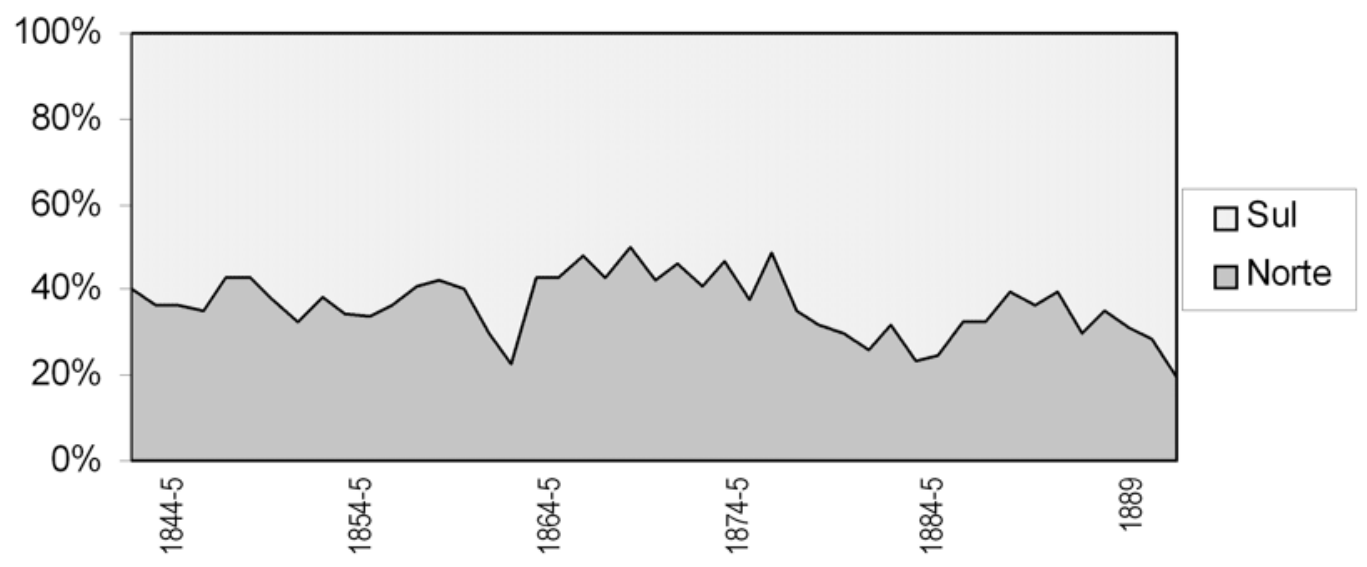




\section{REFERENCIAS BIBLIOGRÁFICAS}

Abreu, Marcelo de Paiva; Corrêa do Lago, Luis A. Property rights and the fiscal and financial systems in Brazil: colonial heritage and the imperial period. In: Bordo, Michael D.; Cortés-Conde, Roberto (eds.), Transferring wealth and power from the old to the new world: monetary and fiscal institutions in the $17^{\text {th }}$ through the $19^{\text {th }}$ centuries. Cambridge: Cambridge University Press, 2001.

Balanço da Receita e Despeza do Imperio. Rio de Janeiro: Typographia Nacional, diversos anos.

Bethell, Leslie; Carvalho, José M. de. 1822-1850. In: Bethell, L. (ed.), Brazil, empire and republic, 1822-1930. Cambridge: Cambridge University Press, 1993.

Brasil. Leis e Decretos. Colleçãa de leis do império do Brazil de 1832. Rio de Janeiro: Typographia Nacional, 1874.

Brasil. Ministério da Agricultura, Industria e Commercio, Directoria do Serviço de Estatística. Finanças - quadros synopticos da receita e despeza do Brazil (periodo de 1822 a 1913). Rio de Janeiro: Typographia do Ministerio da Agricultura, 1914.

. Ministério da Fazenda. Exposição contendo as principaes disposições sobre os artigos da receita do império, organisada de accordo com a Lei do Orçamento n. 3.140, de 30 de outubro de 1882 para o exercício de 1882-1883 e 1883-1884. Rio de Janeiro: Typographia Nacional, 1884.

Breve noticia do estado financeiro das provincias, organisada por ordem de S. Ex. Sr. Barão de Cotegipe, Presidente do Conselho de Ministros. Rio de Janeiro: Imprensa Nacional, 1887.

Buescu, Mircea. História administrativa do Brasil: organização e administração do Ministério da Fazenda no império. Brasília: Funcep, 1984.

Carmagnani, Marcello. Estado y mercado: la economía pública del liberalismo mexicano, 1850-1911. México: El Colegio de México/Fundo de Cultura Económica, 1994.

Carreira, Liberato de Castro. História financeira e orçamentária do império no Brasil. Brasília e Rio de Janeiro: Senado Federal e Casa de Rui Barbosa, 1980, 2 vols.

Carvalho, José Murilo de. Federalismo e centralização no império brasileiro: história e argumento. In: Pontos e bordados: escritos de história e política. Belo Horizonte: Editora da UFMG, 1999.

- Teatro das sombras: a política imperial. $2^{\mathrm{a}} \mathrm{ed}$. rev. Rio de Janeiro: Editora da UFRJ, Relume-Dumará, 1996.

Castro, Paulo Pereira de. A experiência republicana, 1831-1840. In: Buarque de Holanda, Sérgio (dir.), História geval da civilização brasileira. $4^{\mathrm{a}} \mathrm{ed}$. Tomo II, $2^{\circ}$ volume. São Paulo: Difel, 1985. 
Cavalcanti, Amaro. Resenha financeira do ex-império do Brasil em 1889. Rio de Janeiro: Imprensa Nacional, 1890.

Colson, Frank. The destruction of a revolution: polity, economy and society in Brazil, 1870-1891. Tese de Ph.D. não publicada, Princeton University.

Década Republicana. Brasília: Editora da UnB, 4ª ed. rev. e atualizada, 1986.

Deveza, Guilherme. Política tributária no período imperial. In: Buarque de Holanda, Sérgio (dir.), História geral da civilização brasileira. $4^{\mathrm{a}} \mathrm{ed}$. Tomo II, $4^{\mathrm{O}}$ volume. São Paulo: Difel, 1985.

Dolhnikoff, Miriam. O pacto imperial: origens do federalismo no Brasil. São Paulo: Globo, 2005.

Ferreira, Gabriela Nunes. Centralização e descentralização no império - o debate entre Tavares Bastos e Visconde de Uruguai. São Paulo: Ed. 34, 1999.

Goldsmith, Raymond W. Brasil 1850-1984: desenvolvimento financeiro sob um século de inflação. São Paulo: Harper \& Row do Brasil, 1986.

Graham, Richard. Government expenditures and political change in Brazil, 18801899: who got what. Journal of Interamerican Studies and World Affairs, v. 19, n. 3, p. 339-368, August 1977.

IBGE. Estatísticas históricas do Brasil. Séries Estatísticas Retrospectivas, v. 3. Rio de Janeiro: IBGE, 1987.

Imperiaes Resoluções do Conselho de Estado na Secção de Fazenda, desde o anno em que começou a funccionar o conselho até o presente. Rio de Janeiro: Typografia Nacional, 12 vols.

Mello, Evaldo Cabral de. O norte agrário e o império, 1871-1899. 2ª ed. Rio de Janeiro: Topbooks, 1999.

Musgrave, Richard; Musgrave, Peggy. Public finance in theory and practice. Nova York: McGraw-Hill, 1973.

Tavares Bastos, Aureliano Cândido. A provincia - estudo sobre a descentralização no Brasil. 2a ed. São Paulo: Cia. Editora Nacional, 1937.

Uruguai, Visconde de. Ensaios sobre o direito administrativo. In: Carvalho, José M. de (org.), Visconde do Uruguai. São Paulo: Ed. 34, 2002 (Coleção Formadores do Brasil).

. Estudos práticos sobre a administração das provincias no Brasil. Rio de Janeiro: Typographia Nacional, 2 vols., 1865.

Veiga Filho, João Pedro. Manual da sciencia das finanças. $2^{\text {a }}$ ed. São Paulo: Espindola \& Companhia, 1906. 